\title{
REFLECTION
}

\section{A Public Celebration of a Personal Doctor}

\author{
William R. Pbillips, MD, MPH \\ Larry A. Green, $M D^{2}$ \\ 'Department of Family Medicine, Univer- \\ sity of Washington, Seattle, Washington \\ ${ }^{2}$ Department of Family Medicine, Univer- \\ sity of Colorado Denver, Aurora, Colorado
}

\begin{abstract}
The life of a family doctor is engaged with the people, families, and community he or she serves. Caring changes lives. Yet, we seldom have the opportunity to hear the gratitude or to reflect upon the privilege. In this essay, two family doctors share the experience of seeing a community celebrate the life of their doctor. In these public reflections on their personal doctor, folks reveal how he saw their needs, understood their fears, and partnered with them to create futures. Their stories are compelling evidence that personal doctoring is alive and well and held deeply in the heart of America.
\end{abstract}

Ann Fam Med 2010;8:362-365. doi:10.1370/afm.1094.

$\mathrm{T}$ The high school gymnasium in the small town of Cle Elum has seen all sorts of celebrations. Dusty banners hanging from the rafters remind young and old of past victories over teams from other small towns scattered across the Cascade Mountains, the evergreen spine that divides the state of Washington.

This time, however, the generations were crowding in to share, not a victory, but a loss. The town's family doctor of 33 years, our friend John Anderson, had fallen victim to malignant melanoma at a young 63 years.

We came for personal reasons but witnessed a public process. We came to respect a friend and colleague, but were drawn into the experience of a community sharing the loss of its family doctor.

Transitions test our strengths, weaknesses, and values. For a family those times are often birth, marriage, illness, and death. Now the US system of health care faces a time of transition and transformation. This national transition will no doubt bring both ups and downs. We will need to make difficult choices and important commitments.

As the memorial service unfolded, we saw relationships, heard histories, and felt community. It was powerful testimony to the value that personal doctoring offers to patients, families, communities, and to the future. By bearing witness to this event, we call upon the clinicians and policy makers engineering health care reform to preserve the process of personal doctoring.

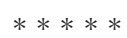

People draw together as they enter the gym: wheat farmers and loggers, business owners and schoolteachers, heavy equipment operators and grandmothers. They gather from around the state and some from across the country. The people who care are there: nurses and doctors and team members from the hospital and clinic. Many are patients; some are neighbors or local business colleagues. All consider themselves friends.

They file in past photos posted on the gym wall and fill the folding chairs set out on the basketball court. The crowd extends up high into the bleachers, with a proud preference for the home team side. The doctor's widow, a well-loved teacher in the local schools, sits peacefully in the front row with her children and their children. The lights dim, a home- 
grown video begins, and the scoreboard wall brightens enough to reflect onto the faces of the friends and family sitting near the front.

Scenes from life appear on the wall. Early photos show long hair; later pictures show less. We see scenes from clinic and hospital, home and garden, ski slope and hiking trail. Almost every picture includes other people. Family was foremost: wife, then children, then - with the warmest glow on John's face-grandchildren. We do not get to see all the late nights and professional frustrations, but we do see John's energy and ambition in a photo of him sitting atop his old red tractor, ready to move the earth. By the end of the show, every face has cracked a smile and every eye has shed a tear.

The service proceeds with music from a hometown duet of voice and piano and a nondenominational invocation. The host introduces the first speaker on the program, a local business leader who recalls from more than 30 years ago his telephone conversation with a young doctor still in residency across the continent. He tells us how he was open with the doctor about the dismal situation the community had long faced: unmet medical needs, a revolving door for doctors (maybe 30 faces over 20 years, none of which anyone really remembered), and a hospital with dilapidated facilities, out-of-date equipment, and no accreditation. They spoke of a new program called the National Health Service Corps (NHSC) that might offer help to such medically impoverished communities. This young doctor wanted to serve in the NHSC, and he wanted to know more about the community, its people, and their needs. The speaker reports, "I knew immediately that I was speaking with a physician willing to take on a big challenge." He then tells a tale of relationships that endured more than 3 decades, partnerships amongst the community, clinicians, government agencies, professional societies, and university programs.

Next, the Roman Catholic parish priest tells how he first met the doctor at $2 \mathrm{AM}$, when called to the home of a dying patient. He arrived and entered the darkened sickroom to find the doctor at the bedside, stooping close to the patient. The priest was astounded when the doctor silently eased away from the bedside to create a space for the priest to step in and lead all present in prayer and consolation. He shares with us the question he asked himself that night: "What kind of doctor is this who is there at the final moment in a life and then steps aside for me?"

A local civic leader-like so many in the gathering, a friend-neighbor-patient-steps to the podium. He points to a few of the photos on the gym wall, showing the grinning doctor holding a particularly cute newborn baby. He and his wife had suffered 7 years of private anguish as they tried without success to have children. His favorite photo captured the moment that anguish was relieved, when the couple's newborn adoptive son was delivered to their door, handed to them in their own home by their own doctor.

A fellow physician chronicles the transformation of health care services for the town, indeed for the entire county. Dr Anderson worked until the job was done to organize after-hours care in the mountain town $30 \mathrm{~min}$ utes from the next bigger town (more when the snows drifted up); to upgrade trauma care and transport in this small town on the big highway; and to improve mental health services for the community suffering more than its share of unemployment, disability, and drugs. Cle Elum got its new hospital and clinic. Many joined the town's team to get the permits, raise the funds, and build the facilities, but the speaker credits Dr Anderson with pushing the stone uphill and keeping it rolling until they made it over the top. These projects required someone with John's abundant energy, faith in the future, and compelling leadership. The audience shares a knowing laugh when the speaker adds, "Arguing with Dr Anderson was just a waste of time... He wasn't stubborn or arrogant; he was Norwegian."

A physician partner lets us in on years of back-office conversations with Dr Anderson aimed at solving the problems of individual patients with individual needs. He also recalls coming around the corner to find John crawling on the floor in the hallway, playing with a little patient. A long-time staff member in the clinic marvels at how accurate the doctor could be with a rubber band shot at her through the reception window.

A local Protestant pastor and long-time patient reveals how worried he was when he shared with Dr Anderson his biggest fear: "I might be losing my mind." He shocks the audience with the doctor's response, "He laughed in my face." He then shares his relief when Dr Anderson explained, "You can't be losing your mind. If you were, all my other patients would have told me about it."

After the planned speakers finish, the host offers the microphone to anyone in the gathering who wants to speak. Grandstands full of grateful patients just want to be there to say thank you for "being there" when they needed the doctor. After a thoughtful pause, several people rise to tell their stories of how Dr Anderson had changed their lives.

Several people have come from across the mountains to speak of how Dr Anderson changed the trajectory of their professional careers. A young doctor thinks back to his clerkship days and thanks Dr Anderson for welcoming him into his practice and into his home. That experience was the inspiration he needed to become a rural physician. A middle-aged woman 
who had once worked as a medical assistant in the doctor's office credits him with urging her to return to school to become a physician assistant.

Others rise to give testimony to how the doctor's reach extended beyond this local community. A specialty colleague from the city down the highway explains how Dr Anderson offered his cesarean section skills to provide the back-up essential to recruiting the obstetrician-gynecologist that their community needed. Others-from down the road and around the nation-emphasize his influence on others.

Voices chime in from church. Airfield buddies recall John's love of flying and their yearly pilot physical exams. Travelers and gardeners and hikers share their memories of Dr John away from the office. We get to hear from some of the people who contributed favorite photos to the video.

As we listen, we recall how we knew John as a special family doctor in ways that few in the audience recognize. He was a founder of the national Rural Health Association and through it connected to countless other small towns and health care teams across the nation. His dedication to future family doctors carried him halfway across the state every week for years to personally interview and advocate for rural applicants to medical school. His belief that residencies must train family physicians capable of serving all communities called him to service on the Residency Review Committee, overseeing accreditation by the American Council on Graduate Medical Education. His curiosity about the problems people brought to him spurred him to become a founding member of the Ambulatory Sentinel Practice Network (ASPN), the first nation-wide primary care practice-based research network.

A young woman aspiring to be a writer approaches the podium to share a poem and brings us back into the moment. She has it written out in longhand on a paper place mat. She knows much about the man, if not so much about medicine. (She is John Anderson's daughter-in law.) Still, she understands the essence of the family doctor: "He'd look at you and know, but still / Would stop and listen anyway." She touched the heart, as poets can, of what other speakers had tried to say: "Everyone was important and everything / Held meaning. Patiently organizing the / Details, he caught the wonder and the mystery."

Finally, the host wraps up the recollections and promises the assembly Lutheran coffee and homebaked goodies in the recreation room. Just as we begin to stand, a voice shouts out from the back of the bleachers, "No. One more!" The rugged guy in worn jeans and a Filson work shirt speaks at the top of his shaky voice: "I always did get Dr Anderson and his partner mixed up; they both had mustaches. But one of you came to my dad when he was in a coma and helped us all deal with it. So, I just want to say, 'Thank you to the Doc Andersons everywhere, who practice like this Dr Anderson did."'

At the reception people share more stories. They are still posting photos on the wall, artifacts of special relationships with a special person. Nearly every picture captures joy. Most pictures show John holding on to someone or something: a newborn baby, an elder's hand, his own granddaughter, or a favorite tool. It is his stethoscope in the exam room, a walking stick on a forest trail, or a shovel in the family garden. Many photos show John enjoying his special places: glacierclad peaks, fir-forested valleys, untracked slopes, or the newly tilled back forty. Dr John had become part of the landscape, and the geography of the town just changed.

The memorial service was comfortably incomplete but rich with remembrances, insights, and inspirations. It chronicled a professional life full of challenges met and promises kept, of more successes than failures, more fulfillments than regrets. It also showed us a personal life full of friendships, active enjoyment of the beauties of the natural world, and devotion to the generations of his own family. No one felt the need to exaggerate virtues or downplay the burdens of being a good doctor in a small town; the people who dwelled in this community knew John and the job he did. Visitors heard what locals knew, that it all took time and work and patience. John's recurrent route to success was engaging others in a shared vision and working with them to reach the common goal.

$$
* * * * *
$$

As we departed, we reflected upon the experience we had just shared. Like everyone there, we caught special glimpses of our friend. Most of what we heard and saw that day was about years of service, days (and some nights) of caring, and moments of tenderness. We heard something, too, about his final months of courage and faith. It was not the whole picture of the whole man, but it was the vision of him that people held in their hearts. We realized what we had witnessed: the shared experience of one community to the life and loss of its family doctor.

What we did not hear was talk about technology, systems, or efficiency. Nothing about advanced patient scheduling, disease registries, or service lines. No EHRs, RVUs, or EBM. (There were a few mentions of team huddles and leadership styles, but they were about personality, not productivity.) Instead, we heard stories that affirmed that personal doctors, living in the community and practicing among people they know, can base their medicine on evidence that is richer than randomized clinical trials. 
We heard testimony which confirmed that the family doctor is a reality, even in challenging communities and in difficult times. We saw evidence that people value care and the people who provide it. We felt the force of family medicine, of personal doctoring, practiced with compassion in the context of families and community. The impact deepened when we realized that this saga was local but not unique ${ }_{i}$ that similar celebrations must go on in communities across our nation.

The experience renewed our resolve that-as we work for health care reform, system change, and practice redesign-innovation must empower personal doctoring. No computer, no insurance company, no hospital system can replace the personal doctor. It is not old fashioned, we saw it in the eyes of new mothers. It is not backwater; we heard it from trusted community leaders. It is not a foreign notion suited only for welfare societies; it abides in the hearts of these Americans in this town and in others.

For some 30 years, along with John, we have been on the front lines of innovation in primary care and know the importance of problem solving, improvement, and change. We have come a long way, and we know we still have far to go. But celebrating together with those folks in that gym, with the team banners hanging overhead, reminded us of the generations, traditions, and achievements that make us proud to be family physicians. It was the voice of the young poet that told us the most about John's abiding interest in people, and it was the picture of the newborn that best conveyed his faith in the future.

When we go, we know there will be friends, patients, and stories to celebrate. We wonder: When those pictures are chosen to show us at our best, what will we be holding on to?

To read or post commentaries in response to this article, see it online at http://www.annfammed.org/cgi/content/full/8/4/362.

Submitted August 10, 2009; submitted, revised, December 7, 2009; accepted December 14, 2009.

Key words: Family medicine; family practice; personal doctor; health care reform; individualized medicine; community medicine; personal health services; rural health services; professional-patient relations

Dr Green holds the Epperson Zorn Chair for Innovation in Family Medicine and Primary Care.

Acknowledgment: We thank Keri Anderson for permission to use excerpts for her poem, "Dr John." 